\title{
Demographic Characteristics of Chemistry Teachers in Croatia Affecting the Use of Pre-laboratory Activities in the Classroom
}

\author{
Snježana Smerdel ${ }^{1, \star}$ and Meliha Zejnilagić Hajrić \\ ${ }^{1}$ University of Split, Faculty of Science, Ruđera Boškovića 33, 21000 Split, Croatia \\ ${ }^{2}$ University of Sarajevo, Faculty of Science, Zmaja od Bosne 33-35, 71000 Sarajevo, Bosnia and Herzegovina \\ *Corresponding author: E-mail: ssmerdel@gmail.com
}

Received: 07-07-2019

\begin{abstract}
Pre-laboratory activities are designed to focus the attention of students on some aspects of the experiment they are preparing to do during the week. Previous research has found that such activities reduce the cognitive load in laboratory time and tend to increase the efficiency of students' laboratory work. This research aims at comparing the importance of demographic characteristics affecting the teachers' use of pre-laboratory activities in a chemistry class. In the frame of the quantitative survey research, an online questionnaire was completed by 166 chemistry teachers from all regions in Croatia. In pre-laboratory sessions, the teachers most commonly used a pre-lab discussion and pre-lab worksheets whereas computer simulations were represented the least. Three characteristics affecting the teachers' use of pre-laboratory activities in chemistry classes were their gender, age and teaching subjects. The teachers' education, teaching experience and school types were nonsignificant characteristics.
\end{abstract}

Keywords: Cognitive load; pre-laboratory activities; pre-learning strategy; secondary chemistry education.

\section{Introduction}

Laboratory activities are learning experiences in which students interact with materials and/or models to observe and understand the natural world. Science educators have suggested that many benefits accrue from engaging students in science laboratory activities. ${ }^{1}$ This includes exposing students to concrete experiences with objects and concepts mentioned in the classroom. ${ }^{2}$ In addition, it allows the connection of macroscopic observations to the abstract representations and symbolizations used in science to be made by facilitating the understanding of chemical concepts. ${ }^{3}$ Literature findings have indicated that the students' preparation for laboratory work should increase the chances of their understanding of what they are doing in the lab. This is intended to avoid a 'cookbook' or 'recipe-following scenario. ${ }^{4}$

This research is focused on the use of various aspects of preparation for laboratory work in Croatian schools, exploring the possible influence of the teachers' demographic profile. The chemistry teachers were required to complete a survey questionnaire about the use of pre-laboratory activities (PLABs) in their teaching practice.
The next section explains the importance of preparing students for laboratory work. Information processing and knowledge building are limited to the working memory capacity but the use of PLABs leads to reducing working memory load in laboratory time.

\section{Theoretical Framework}

\section{1. The Importance of PLABs}

The concept of PLABs is particularly based on ideas developed by Ausubel ${ }^{5}$ (preparing the mind for learning) and Sweller, Van Merrienboer and Paas's ${ }^{6}$ cognitive load theory (CLT). According to CLT, information processing and knowledge building are limited to the working memory capacity. The overloaded working memory capacity does not leave space for thinking and information organization, which results in cognitive overload. ${ }^{7}$ In a laboratory, there is much more information to be processed than necessary. For a novice, all of the information (the bubble, the colour change, the smell, etc.) is potentially important and relevant, while only a limited part of this is important for an expert because of the precise filter available to them. An ex- 
pert has the information held in the long-term memory as prior knowledge, theory and/or previous experience. ${ }^{8}$

PLABs are designed to focus the attention of students on some aspects of the experiment they are preparing to do during the week ${ }^{9}$ in accordance with the selected objectives for experimental work. ${ }^{10}$

According to Johnstone et al., the aim of PLABs is to prepare students to take an intelligent interest in the experiment by knowing where they will go, why they will go there, and how they will get there. ${ }^{4}$ The importance of preparing students for laboratory work by reducing the cognitive load in laboratory time has been highlighted by educators and psychologists, and it has also been the subject of a lot of research. ${ }^{11}$

According to Agustian and Seery, ${ }^{12}$ the advantages of students' preparation in advance of a laboratory session can be classified into four categories:

- Overall - PLABs tend to have a positive impact on learning in the laboratory. ${ }^{8,13}$

- Experimental - PLABs tend to increase the efficiency of students' laboratory work and reduce the time spent on experimental tasks. ${ }^{11}$

- Conceptual - PLABs that prepare students for conceptual aspects of laboratory work tend to result in students performing better in the laboratory. PLABs that present conceptual ideas of laboratory work tend to lead students to feel more autonomous about completing their laboratory work. ${ }^{8,14}$

- Affective - PLABs enable students to feel more confident about laboratory work ${ }^{13,15}$ and/or reduce students' negative feelings towards laboratory classes. ${ }^{16}$

The nature and purpose of PLABs depend on the context and purpose of the laboratory in question. ${ }^{12}$ Rollnick et al. ${ }^{17}$ concluded that the best form of preparation varies from student to student. Some students will prepare thoroughly no matter what obligatory preparation is demanded. Those who are willing in spirit but poorly organized, or those who would skip preparation because of the load of other academic work are the ones who benefit most from the obligatory preparation. ${ }^{17}$

\section{2. Literature Review of PLABs}

In science education literature, the use of various PLABs is extensively described at an undergraduate level. Parallel experiences at a secondary school level are considerably smaller but also vital. ${ }^{18}$ The conventional way of preparing students would be to encourage them to read their laboratory manuals, but these typically overload them with information to be held at the same time. On the other hand, only a limited number of students try to understand or do read the manuals before entering the laboratory. ${ }^{19}$ The literature review revealed the use of various aspects of PLABs, such as pre-laboratory discussions, ${ }^{20}$ pre-lab questionnaires, ${ }^{8}$ pre-lab exercises with solving theoretical problems related to the experiment, ${ }^{9}$ and pre-lab- oratory instructions..$^{21}$ Students can be required to prepare a laboratory notebook in advance with customary information ${ }^{22}$ or complete pre-lab worksheets with questions relevant to a particular experiment. ${ }^{4}$

The results of recent studies indicate frequent use of video demonstrations and online quizzes in advance of laboratory classes, ${ }^{14,15}$ as well as online pre-laboratory assignments. ${ }^{13}$ The videos can consist of voice-over PowerPoints with photographs of laboratory glassware set-up, explanation/description of laboratory procedures, important safety considerations and waste disposal instructions. ${ }^{15}$ The use of quizzes with feedback improves links between theory and practical work by providing immediate feedback to students. ${ }^{13}$ Pre-laboratory software resources and simulations are being increasingly used as preparation for laboratory work and as a way of introducing students to the theory relevant to the experiment, as well as for introducing experimental design aspects. ${ }^{11,18}$

Although these previous studies have been useful, the subject of whether demographic characteristics influence the use of PLABs remains unexplored. Only by comparing them, we can determine their possibly important influence on the teaching practice.

\section{3. Demographic Characteristics in Education}

The relationship between education and demographic characteristics has been described and analyzed in a considerable number of research works. Some studies have investigated of the teacher candidates' attitudes towards teaching profession according to their demographic variables, ${ }^{23}$ then what are the effects of pre-service teachers' demographic features on their concerns about teaching in technology-integrated flipped classrooms ${ }^{24}$ and some have focused on gender differences in mathematics and science. ${ }^{25}$

Recent research mostly has addressed the effects of the teachers' demographic characteristics on their information and communication technology (ICT) readiness, ${ }^{26}$ the integration of ICT into their teaching practices ${ }^{27-29}$ and on the teachers' perceived usefulness of ICT. ${ }^{30}$ According to Koh, Chai and Tsai, ${ }^{31}$ teaching level and teaching experience have significant influence on the teachers' knowledge of using constructivist teaching methods whereas age and gender are not affected.

Despite the literature related to education, any relationship between the use of teaching methods and demographic characteristics remains unclear. In this paper, we have tried to investigate a possible influence of the teachers' demographic characteristics on the use of PLABs in the chemistry classroom.

\section{4. Research Purpose}

In the Croatian education system, there is a lack of relevant scientific research that refers to the importance of pre- 
paring students to reduce the cognitive load during laboratory classes. In addition, beyond the context of Croatia, not much research analyses the use of PLABs in secondary chemistry education. Our study is an attempt to fill these gaps by focusing on these issues in the context of Croatia. The conducted research is the first part of a more comprehensive study within a $\mathrm{PhD}$ project regarding the implementation of the pre-learning strategy into chemistry education.

The main purpose of this research was to determine the frequency of using PLABs for teaching chemistry and at the same time to explore the influence of demographic characteristics on the use of PLABs within the chemistry teacher population. Six specific characteristics were analyzed: gender, age, teacher education, teaching subjects, school type and teaching experience. The research findings should provide direct insight into the actual practice of teachers and their priorities in the selection of certain aspects of PLABs in chemistry teaching. Learning more about the demographic characteristics of chemistry teachers will allow a more detailed analysis and give a more accurate view of the real current situation in Croatian chemistry education, thus preparing the way for methodological intervention strategies.

Research questions. This research intends to provide answers to the following research questions:

1. How often do chemistry teachers use PLABs in their classes?

2. Does the teachers' use of PLABs depend on their demographic characteristics (gender, age, teacher education, teaching subjects, school type and teaching experience)?

\section{Methodology}

This quantitative survey research enables the collection of data about the demographic characteristics of par- ticipants and can also quantify the frequency of using PLABs. A nationwide questionnaire survey was administered to the population of chemistry teachers from the whole of Croatia.

\section{1. Research Participants}

The sampling frame consisted of 600 chemistry teachers from all 21 regions in Croatia whose email addresses were obtained on request from the education advisor database. A total of 166 of the targeted chemistry teachers (27.7\% response rate) completed the online survey, but an ideal representation with regard to the number and gender of chemistry teachers in each region could not be achieved. Most of them were in the City of Zagreb region (24.7\%) and the fewest in the Karlovac region (0.6\%).

The data presented in Table 1 illustrate the profile of the participants for this research. The results revealed that the majority of the participants were female (88.6\%), which presents a realistic picture of the great underrepresentation of the male gender in Croatian primary and secondary schools. Likewise, the majority of the participants' age was over 45 years (44.5\%) whereas $22.3 \%$ were under 36 years old.

According to their education, a total of $69.3 \%$ of the participants were teachers whilst others were engineering educators with pedagogical knowledge. The results presented in Table 1 indicate that $63.3 \%$ of the participants had over 11 years of teaching experience. About a half of the participants $(46.4 \%)$ teach in a general high school, while slightly more than one-third $(37.3 \%)$ teach in a vocational school. The highest percentage belongs to those who teach only chemistry (51.2\%), followed by those who teach chemistry and biology (44.0\%).

An approval of the protocol by an institutional review board from the Faculty of Science of the University of

Table 1. Description of Participants' Demographic Characteristics $(\mathrm{N}=166)$ by Groups

\begin{tabular}{lccc}
\hline Demographic characteristic & Group & N & \% \\
\hline Gender & Male & 19 & 11.4 \\
& Female & 147 & 88.6 \\
Age (years) & $<36$ & 37 & 22.3 \\
& $36-45$ & 55 & 33.2 \\
Teacher's Education & $>45$ & 74 & 44.5 \\
& Teacher & 115 & 69.3 \\
Teaching Experience & Engineer/Educator & 51 & 30.7 \\
& $<11$ & 61 & 36.7 \\
School Types & $11-25$ & 78 & 47.0 \\
& $>25$ & 27 & 16.3 \\
& Primary & 27 & 16.3 \\
Teaching Subjects & Vocational & 62 & 37.3 \\
& High School & 77 & 46.4 \\
& Chemistry & 85 & 51.2 \\
& Chemistry/Biology & 73 & 44.0 \\
& Chemistry/Physics & 8 & 4.8 \\
\hline
\end{tabular}


Split, was obtained. The participation in this survey research was completely voluntary, and all participants were informed of the research purpose, the research content and the benefit that included their contribution to the advancement of the education research. The teachers' consent to participate in this research freely and consciously was obtained from all participants. The confidentiality and anonymity were a priority for the participants of the research.

\section{2. Research Instrument}

The Using the Pre-Laboratory Activities Questionnaire (UPLAQ) (Appendix 1) as designed for the purpose of this research and based on the data obtained from a review of existing literature ${ }^{4,32}$ was made with the free web survey tool Google Docs. The UPLAQ consists of 15 items - 14 close-ended items and 1 open-ended item. The first seven items include demographic characteristics of chemistry teachers (region, gender, age, education, teaching subjects, school type, and teaching experience). The remaining seven close-ended items relate to the research topic required the participants to estimate the frequency of the use of various forms of PLABs:

- reading the laboratory manual,

- pre-lab discussion about the most important points of an experiment,

- completing pre-lab worksheets,

- solving theoretical problems related to the experiment,

- using audiovisual materials,

- solving online pre-lab assignments,

- doing computer simulations of experiments.

In order to suit the purpose of this research and facilitate administration, the Likert six-point scale of frequency (1-never, 2-sometimes, 3-usually, 4-often, 5-very often, 6-always) was chosen. In order to avoid restricting the teachers to choose among the seven types of PLABs, the following open-ended question was included at the end of UPLAQ: "If you use other types of PLABs not mentioned here, please describe them briefly".

The credibility of the applied instrument was assured by considering the test validity and reliability. The content validity was estimated through the work of two university professors in the field of Chemistry Teaching and two high school chemistry teachers. The experts independently examined the questionnaire regarding the clarity and meaningfulness of the questionnaire's claims, the applied terminology and the diversity in pre-learning activities used, so the UPLAQ was revised according to the given recommendations.

The next step in the development of the instrument was a pilot research (March 2017) carried out with chemistry and biology teachers in primary and secondary schools in one Croatian region and focused on the quality control of the questionnaire and data collection for its op- timisation. ${ }^{33}$ Seven questionnaire items, which provide information about the frequency of the use of various PLABs, were used as a basis for determining the internal consistency. The internal consistency reliabilities using the Cronbach a coefficient was calculated .79 for all items. ${ }^{34}$ The results indicated that the scale had an acceptable level of reliability.

\section{3. Research Context}

In this research, an email invitation with a link to access the UPLAQ was distributed at the same time to 600 chemistry teachers from the whole Croatia.

Schooling in Croatia consists of eight primary grades and four secondary grades. Chemistry is a subject for 7 th8 th grade primary students and 1st-4th grade secondary students, depending on the school type. Most schools hold two 45-minute chemistry lessons per week. In the first grade of general high school, general chemistry is discussed, in the second physical, in the third inorganic and in the fourth organic chemistry.

During June and July 2017, the UPLAQ was completed online by 166 chemistry teachers. Prior to filling it, the teachers had to read the introductory text explaining the research purpose, result process and instructions for completing the UPLAQ. The time frame for completing the web survey was not limited. The researchers were available via email for addressing any problems or comments regarding the survey questionnaire throughout the research.

\section{4. Data Analysis}

Based on the set research questions and hypotheses, the collected data were analyzed with the statistical package IBM SPSS Statistics 21.0 where descriptive and inferential analyses were employed. Descriptive statistics such as a frequency distribution was employed to describe the general data of this research. For the purpose of revealing any differences between the selected demographic characteristics and the use of PLABs, inferential analyses such as non-parametric two-tailed Mann-Whitney U-test and Kruskal-Wallis $\mathrm{H}$ test were utilized. These tests were chosen since they enabled the testing of hypotheses on small and asymmetrically distributed samples.

\section{Results}

\section{1. Frequency of the Use of PLABs}

The first research question was: How often do chemistry teachers use PLABs in their classes? The descriptive statistics analysis was carried out in order to calculate the frequency percentage of the teachers' responses for the UPLAQ data on the overall sample (Fig. 1). It can be seen that the teachers most commonly use a pre-lab discussion 
(S2) Students are prepared for laboratory work by pre-lab discussion.

(S3) Students are prepared for laboratory work by completing pre-lab worksheets.

(S4) Students are prepared for laboratory work by solving theoretical problems.

(S1) Students are prepared for laboratory work by reading a pre-lab manual.

(S5) Students are prepared for laboratory work by using audiovisual materials.

(S6) Students are prepared for laboratory work by solving online pre-lab assignments.

(S7) Students are prepared for laboratory work by computer simulations.

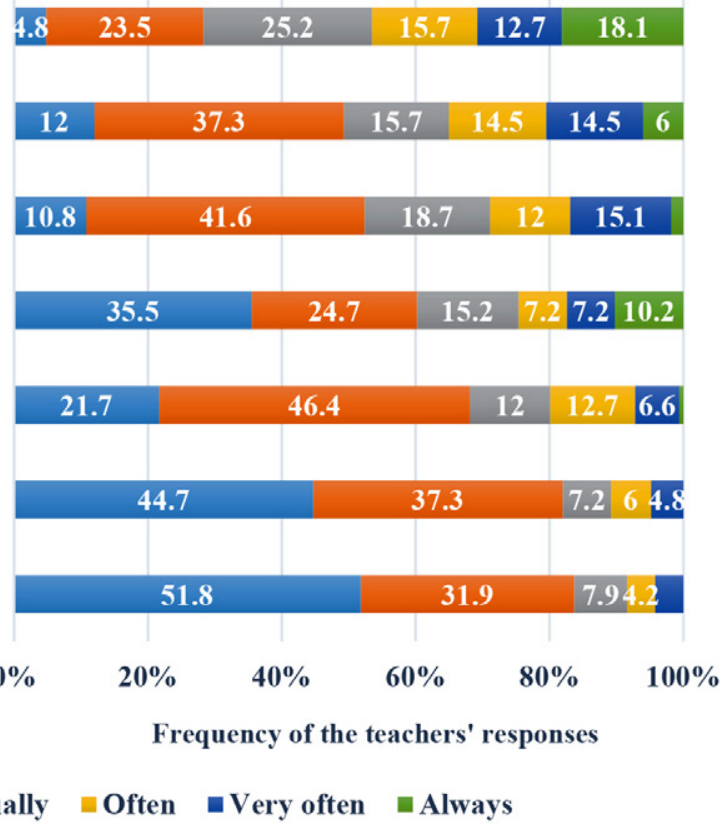

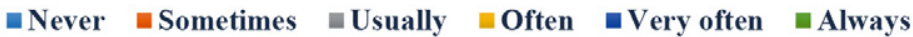

Figure 1: The frequency percentage of teachers' responses $(\mathrm{N}=166)$ to the online survey of Using the Pre-Laboratory Activities, by statements $(\mathrm{S})$

(S2). Almost a half of the teachers (46.5\%) use the pre-lab discussion often to always.

From the results presented in Fig. 1, the second most commonly used activity is completing pre-lab worksheets (S3), and about one-third of the teachers (35.0\%) often to always assign completing pre-lab worksheets to the students. The least use was noticed for computer simulations (S7). The results show that about a half of the participants never use computer simulations as PLABs, whereas almost one-third do that sometimes. A slightly higher use was obtained for solving online pre-lab assignments (S6). These activities are sometimes carried out by $37.3 \%$ of the participants whereas $44.7 \%$ never use them.

A smaller number of the teachers responded to the open-ended question "If you use other types of PLABs not mentioned in the questionnaire, please describe them briefly". The following responses were obtained:

"A lot of things from the survey questions are used after the experiment."

"At the end of the lesson, I always tell the students what we are going to do in the next laboratory work."

"I publish in our Facebook group some type of a riddle or questions which refer to the exercise from laboratory work which will be graded during the next lesson. Some students research it, so they have an advantage in doing laboratory work."

Other answers contemplated the technical and syllabus possibilities of teaching (e.g. "the experimental work is done in a classroom without computer equipment", "we do not have classic laboratory exercises at school as they have not been envisaged in the syllabus"). Differences in the use of PLABs are examined and discussed in detail in the following subsection.

\section{2. Differences in the Use of PLABs Regarding Demographic Characteristics}

Each group of data was tested for normality with the Kolmogorov-Smirnov test with Lilliefors' significance. ${ }^{35}$ The results $(p<.05)$ indicated that the collected data did not satisfy the requirements of a normal distribution. The assumption of the independence of observations was met; there were two or more independent groups compared at the ordinal level.

In order to provide a complete answer to the second research question posed in this paper: Does the teachers' use of PLABs depend on their demographic characteristics (gender, age, teacher education, teaching subjects, school type and teaching experience) and the six null hypotheses associated with this research question, the non-parametric Mann-Whitney $\mathrm{U}$ test and Kruskal-Wallis $\mathrm{H}$ test (level of significance at $p<.05)$ were applied. For this analysis, the teachers' uses of seven aspects of PLABs were defined as dependent variables while demographic characteristics were defined as independent variables.

\section{2. 1. Gender Differences in the Use of PLABs}

For an evaluation of gender differences in the teachers' responses, the two-tailed non-parametric MannWhitney $\mathrm{U}$ test was used for two independent groups: group 1 - male $(N=19)$ and group 2 - female $(N=147)$.

Table 2 shows higher mean rank (MR) values for male participants in each of the seven statements (S). Statistically significant gender differences were obtained in S1: Students are prepared for laboratory work by reading the pre-lab manual (Mann-Whitney $U=1016.500, Z=-1.993$, 
Table 2. The results of the Mann-Whitney U test (two-tailed) of statistically significant gender differences in the chemistry teachers' use of pre-laboratory activities $(N($ male $)=19 ; N($ female $)=147)$

\begin{tabular}{|c|c|c|c|c|c|c|}
\hline Items & Pre-laboratory Activities & Group $^{\mathrm{a}}$ & Mean Rank & $U$ & $Z$ & $p$ \\
\hline \multirow[t]{2}{*}{1} & \multirow[t]{2}{*}{ Pre-lab manual } & Male & 103.50 & \multirow[t]{2}{*}{1016.500} & \multirow[t]{2}{*}{-1.993} & \multirow[t]{2}{*}{.046} \\
\hline & & Female & 80.91 & & & \\
\hline \multirow[t]{2}{*}{2} & \multirow[t]{2}{*}{ Pre-lab discussion } & Male & 106.24 & \multirow[t]{2}{*}{964.500} & \multirow{2}{*}{-2.238} & \multirow[t]{2}{*}{.025} \\
\hline & & Female & 80.56 & & & \\
\hline \multirow[t]{2}{*}{3} & \multirow[t]{2}{*}{ Pre-lab worksheets } & Male & 95.55 & \multirow[t]{2}{*}{1167.500} & \multirow[t]{2}{*}{-1.201} & \multirow[t]{2}{*}{.230} \\
\hline & & Female & 81.94 & & & \\
\hline \multirow[t]{2}{*}{4} & \multirow[t]{2}{*}{ Solving theoretical problems } & Male & 101.00 & \multirow[t]{2}{*}{1064.000} & \multirow[t]{2}{*}{-1.763} & \multirow[t]{2}{*}{.078} \\
\hline & & Female & 81.24 & & & \\
\hline \multirow[t]{2}{*}{5} & \multirow[t]{2}{*}{ Audiovisual materials } & Male & 83.84 & \multirow[t]{2}{*}{1390.000} & \multirow[t]{2}{*}{-0.035} & \multirow[t]{2}{*}{.972} \\
\hline & & Female & 83.46 & & & \\
\hline \multirow[t]{2}{*}{6} & \multirow[t]{2}{*}{ Online assignments } & Male & 85.82 & \multirow[t]{2}{*}{1352.500} & \multirow[t]{2}{*}{-0.241} & \multirow[t]{2}{*}{.810} \\
\hline & & Female & 83.20 & & & \\
\hline \multirow[t]{2}{*}{7} & \multirow[t]{2}{*}{ Computer simulations } & Male & 92.11 & \multirow[t]{2}{*}{1233.000} & \multirow[t]{2}{*}{-0.911} & \multirow[t]{2}{*}{.362} \\
\hline & & Female & 82.39 & & & \\
\hline
\end{tabular}

${ }^{a}$ Grouping Variable: Gender

$N_{1}=147, N_{2}=19, p=.046$, two-tailed) and in S2: Students are prepared for laboratory work by a pre-lab discussion (Mann-Whitney $U=964.500, Z=-2.238, N_{1}=147, N_{2}=$ $19, p=.025$, two-tailed).

In order to provide a clear description of the size of the observed statistically significant influences, the effect sizes were evaluated using the $r$ benchmarks, provided by Cohen, ${ }^{36}$ following the formula: ${ }^{37}$

$$
R=z / \sqrt{ } \mathrm{N}
$$

Small effect sizes were determined for the use of reading pre-lab manual activity $(r=-0.15)$ and for the use of $a$ pre-lab discussion activity $(r=-0.17)$.

\section{2. 2. Teaching Subjects Differences in the Use of PLABs}

In order to evaluate teaching subjects differences in the teachers' responses, the non-parametric Kruskal-Wallis $\mathrm{H}$ test was used for three independent groups: group 1

Table 3. The results of the Kruskal-Wallis $H$ test of statistically significant differences in the chemistry teachers' use of pre-laboratory activities regarding teaching subjects $(N($ chem $)=85 ; N($ chem $/$ bio $)=73 ; N($ chem $/$ phys $)=8)$

\begin{tabular}{|c|c|c|c|c|c|}
\hline Items & Pre-laboratory activities & Group $^{a}$ & Mean Rank & $\chi^{2}$ & $p$ \\
\hline \multirow[t]{3}{*}{1} & \multirow[t]{3}{*}{ Pre-lab manual } & Chem & 83.56 & \multirow[t]{3}{*}{1.686} & \multirow[t]{3}{*}{.430} \\
\hline & & Chem/Bio & 81.22 & & \\
\hline & & Chem/Phys & 103.69 & & \\
\hline \multirow[t]{3}{*}{2} & \multirow[t]{3}{*}{ Pre-lab discussion } & Chem & 88.61 & \multirow[t]{3}{*}{5.401} & \multirow[t]{3}{*}{.067} \\
\hline & & Chem/Bio & 74.97 & & \\
\hline & & Chem/Phys & 107.06 & & \\
\hline \multirow[t]{3}{*}{3} & \multirow{3}{*}{ Pre-lab worksheets } & Chem & 81.85 & \multirow[t]{3}{*}{1.223} & \multirow[t]{3}{*}{.542} \\
\hline & & Chem/Bio & 83.51 & & \\
\hline & & Chem/Phys & 100.88 & & \\
\hline \multirow[t]{3}{*}{4} & \multirow[t]{3}{*}{ Solving theoretical problems } & Chem & 84.61 & \multirow[t]{3}{*}{6.078} & \multirow[t]{3}{*}{.048} \\
\hline & & Chem/Bio & 78.20 & & \\
\hline & & Chem/Phys & 120.06 & & \\
\hline \multirow[t]{3}{*}{5} & \multirow[t]{3}{*}{ Audiovisual materials } & Chem & 79.76 & \multirow[t]{3}{*}{1.248} & \multirow[t]{3}{*}{.536} \\
\hline & & Chem/Bio & 87.83 & & \\
\hline & & Chem/Phys & 83.69 & & \\
\hline \multirow[t]{3}{*}{6} & \multirow[t]{3}{*}{ Online assignments } & Chem & 85.18 & \multirow[t]{3}{*}{4.729} & \multirow[t]{3}{*}{.094} \\
\hline & & Chem/Bio & 78.27 & & \\
\hline & & Chem/Phys & 113.38 & & \\
\hline \multirow[t]{3}{*}{7} & \multirow[t]{3}{*}{ Computer simulations } & Chem & 82.02 & \multirow[t]{3}{*}{4.502} & \multirow[t]{3}{*}{.105} \\
\hline & & Chem/Bio & 81.72 & & \\
\hline & & Chem/Phys & 115.50 & & \\
\hline
\end{tabular}

${ }^{a}$ Grouping Variable: Teaching Subjects 
- chemistry $(N=85)$, group 2 - chemistry/biology $(N=$ 73 ) and group 3 - chemistry/physics $(N=8)$.

According to Table 3, the mean rank (MR) values were the highest for chemistry/physics teachers in most statements, except in S5: Students are prepared for laboratory work by using audiovisual materials. The KruskalWallis $\mathrm{H}$ test showed a statistically significant difference regarding teaching subjects in S4: Students are prepared for laboratory work by solving theoretical problems $\left(\chi^{2}(2)=\right.$ $6.078, p=.048)$ with the highest mean rank value for chemistry/physics teachers $(\mathrm{MR}=120.06)$.

The post-hoc Mann-Whitney U test was used to identify the cause of the effect in the Kruskal-Wallis $\mathrm{H}$ test. The results in Table 4 revealed a significant difference between chemistry/biology and chemistry/physics regarding the use of solving theoretical problems $(U=-41.864, p=.044)$.

Table 4. Group comparison with post-hoc Mann-Whitney tests (two-tailed) in the chemistry teachers' use of pre-laboratory activities regarding teaching subjects

\begin{tabular}{lcr}
\hline Pairs of Groups & $\boldsymbol{U}$ & $\boldsymbol{p}$ \\
\hline Chem - Chem/Bio & 6.413 & 1.000 \\
Chem/Bio - Chem/Phys & -41.864 & .044 \\
Chem/Phys - Chem & -35.451 & .111 \\
\hline
\end{tabular}

\section{2. 3. Age Differences in the Use of PLABs}

In order to evaluate age differences in the teachers' responses, the non-parametric Kruskal-Wallis $\mathrm{H}$ test was used. The amount of the obtained quantitative data was reduced with classification into three independent groups: 1) under 36 years (containing groups of under 30 years old and 30-35 years old); 2) 36-45 years (containing groups of 36-40 years old and 41-45 years old); 3 ) over 45 years (containing groups of 46-55 years old and over 55 years old).

In Table 5, the largest mean rank difference can be noted in S3: Students are prepared for laboratory work by completing pre-lab worksheets, with the highest MR value (101.18) for group 1 (under 36 years). The results of the Kruskal-Wallis H test $\left(\chi^{2}(2)=7.494, p=0.024\right)$ showed a statistically significant difference.

The results of the Mann-Whitney U test $(p>.05)$ showed that there were no statistically significant differences in the overall use of PLABs regarding the teachers' education (teacher, engineer/educator). Likewise, the results of the Kruskal-Wallis H test $(p>0.05)$ showed that there were no statistically significant differences in the overall use of PLABs regarding both teaching experience and school types.

\section{Discussion}

The findings of the present research were obtained by a survey of chemistry teachers from all regions of Croatia about the use of various aspects of PLABs. The research sought to offer an overview of the actual practice in

Table 5. The results of the Kruskal-Wallis $\mathrm{H}$ test of statistically significant differences in the chemistry teachers' use of pre-laboratory activities regarding the age of teachers $(N(<36)=37 ; N(36-45)=55$; $N(>45)=74)$

\begin{tabular}{|c|c|c|c|c|c|}
\hline Items & Pre-laboratory activities & Group $^{a}$ & Mean Rank & $x^{2}$ & $p$ \\
\hline \multirow[t]{3}{*}{1} & \multirow[t]{3}{*}{ Pre-lab manual } & $<36$ years & 88.15 & \multirow[t]{3}{*}{0.917} & \multirow[t]{3}{*}{.632} \\
\hline & & $36-45$ years & 79.02 & & \\
\hline & & $>45$ years & 84.51 & & \\
\hline \multirow[t]{3}{*}{2} & \multirow[t]{3}{*}{ Pre-lab discussion } & $<36$ years & 85.68 & \multirow[t]{3}{*}{1.851} & \multirow[t]{3}{*}{.396} \\
\hline & & $36-45$ years & 76.52 & & \\
\hline & & $>45$ years & 87.60 & & \\
\hline \multirow[t]{3}{*}{3} & \multirow[t]{3}{*}{ Pre-lab worksheets } & $<36$ years & 101.18 & \multirow[t]{3}{*}{7.494} & \multirow[t]{3}{*}{.024} \\
\hline & & $36-45$ years & 82.15 & & \\
\hline & & $>45$ years & 75.66 & & \\
\hline \multirow[t]{3}{*}{4} & \multirow{3}{*}{$\begin{array}{l}\text { Solving theoretical } \\
\text { problems }\end{array}$} & $<36$ years & 91.59 & \multirow[t]{3}{*}{1.539} & \multirow[t]{3}{*}{.463} \\
\hline & & $36-45$ years & 79.99 & & \\
\hline & & $>45$ years & 82.06 & & \\
\hline \multirow[t]{3}{*}{5} & \multirow{3}{*}{$\begin{array}{l}\text { Audiovisual } \\
\text { materials }\end{array}$} & $<36$ years & 85.18 & \multirow[t]{3}{*}{0.543} & \multirow[t]{3}{*}{.762} \\
\hline & & $36-45$ years & 79.83 & & \\
\hline & & $>45$ years & 85.39 & & \\
\hline \multirow[t]{3}{*}{6} & \multirow[t]{3}{*}{ Online assignments } & $<36$ years & 80.39 & \multirow[t]{3}{*}{0.233} & \multirow[t]{3}{*}{.890} \\
\hline & & $36-45$ years & 84.55 & & \\
\hline & & $>45$ years & 84.27 & & \\
\hline \multirow[t]{3}{*}{7} & \multirow{3}{*}{$\begin{array}{l}\text { Computer } \\
\text { simulations }\end{array}$} & $<36$ years & 89.85 & \multirow[t]{3}{*}{1.152} & \multirow[t]{3}{*}{.562} \\
\hline & & $36-45$ years & 79.96 & & \\
\hline & & $>45$ years & 82.95 & & \\
\hline
\end{tabular}

${ }^{a}$ Grouping Variable: Age of Teachers 
chemistry teaching concerning the teachers' demographic characteristics and their use of PLABs.

The teachers' demographic characteristics that affected the use of PLABs include their age, gender and the subjects they teach. The use of PLABs was shown to be greater among male teachers ${ }^{26}$ who are relatively young ${ }^{30}$ and teach both chemistry and physics. The results of our study indicate a significant difference between genders in the use of PLABs in chemistry practice although the influence of this variable is small. These findings are consistent with the previous study ${ }^{23,24,26}$ that found a significant gender difference (1) in their attitude of teaching profession, ${ }^{23}$ (2) in the pre-service teachers' concerns about teaching in technology-integrated flipped classrooms, ${ }^{24}$ and (3) in the teachers' ICT readiness, ${ }^{26}$ but our findings are opposite to some previous studies in education. ${ }^{27-29,31}$ According to the presented results, in pre-laboratory sessions, male teachers most commonly use a pre-lab discussion by setting up questions that serve as the focus for discussion and guide inquiry in the lab as presented in the previous research. ${ }^{20}$ The conventional way of preparing students for laboratory work is reading laboratory manuals, but Reid and Shah find that these typically overload them with information to be held at the same time. ${ }^{19}$ The pre-lab manual, which contains the explanation of laboratory procedures and important safety considerations, was mostly used by male teachers.

Pre-lab worksheets, described in Johnstone et al.s study, ${ }^{4}$ are the second aspect of PLABs often used in chemistry teaching but vary by the teachers' age. The teachers under 36 years of age with typically less teaching experience compared to their older colleagues ${ }^{29}$ more often use PLABs in their teaching practice, which is consistent with the previous study showing that a higher age may be associated with higher levels of perceiving the problems and obstacles of the use of ICT for teaching and learning. ${ }^{30}$ However, our results are opposite to most of the relevant researches. ${ }^{23,26,28,29,31}$

Our findings revealed that the teaching subjects affect the use of PLABs in teaching practices. Chemistry/ physics teachers use solving theoretical problems activities with a more significant frequency than chemistry/biology teachers. This result was similar to those of other studies $^{24,27}$ indicating that the subject of the teaching programs matters has to be considered in the integration of ICT into teaching practices. ${ }^{27}$

On the other hand, the lowest use appeared in solving online assessments and doing computer simulations, although studies show that the use of quizzes provides immediate feedback to students by improving links between theory and practical work. ${ }^{13}$ The use of pre-lab computer simulations, aimed at the theory central to the laboratory exercise, reduces the cognitive load in students. ${ }^{11}$

Even though the responses "never" and "sometimes" were very frequent for certain questionnaire items, it cannot be claimed that the chemistry teachers used the sug- gested PLABs insufficiently. Perhaps every participating teacher used at least one form of PLABs for every laboratory class. An open-ended question was included at the end of the UPLAQ to allow a full picture of the teachers' use of PLABs. The teachers announced using laboratory work at the following class or posting interesting tasks on Facebook, which is in line with the affinities of today's student generations.

Regardless of the observed statistical differences by gender, age and teaching subjects, it cannot be claimed with sufficient probability that these differences exist in the entire population of teachers represented by our sample. The use of all PLABs was more frequent in male teachers and in chemistry/physics teachers (except using audiovisual materials) but the lack of significant differences was likely due to uneven group sizes (gender, $N_{1}=19, N_{2}=147$ and teaching subjects, $N_{1}=85, N_{2}=73, N_{3}=8$ ). The likelihood that the test correctly rejected the null hypothesis decreased as the group sizes were more uneven.

Several limitations should be taken into account when drawing conclusions from this research. First, email addresses of 600 teachers were obtained on request from the education advisor database but an unknown proportion of the entire population was not sampled. The obtained sample of 166 teachers may not represent the entire chemistry teacher population accurately. The research results cannot be used in generalizations about the entire population. However, by applying appropriate statistical tests, useful conclusions on the population could be extrapolated.

The second limitation is that all conclusions must be considered within the context of the limitations that arise from the nature of the survey research itself. Although the self-administered online questionnaire allows increased anonymity, which increases the likelihood of honest responses, ${ }^{38}$ there was no way of telling how truthful the participants were - they could be forgetful or did not think within the full context of the situation and responded based on their own interpretation of statements of the questionnaire.

The third and largest limitation in testing possible differences in the use of PLABs was the impossibility of establishing the equivalence of samples. Very uneven sample sizes regarding gender provide a realistic picture of male underrepresentation in Croatian primary and secondary schools, and such a bias could be difficult to avoid. However, the assumption is that the groups were homogeneous in social status, profession and level of education. Despite these limitations, the present research provided a satisfactory analysis of the actual current situation in the Croatian chemistry education regarding the use of PLABs.

\section{Conclusions}

This survey research was aimed at examining the use of PLABs for chemistry teaching. Seven aspects of PLABs 
were offered in UPLAQ to get direct insight into how often chemistry teachers use PLABs in their classes. At the same time, the influence of six demographic characteristics on the use of PLABs in the chemistry teacher population was explored.

In pre-laboratory sessions, teachers most commonly used a pre-lab discussion and pre-lab worksheets whereas PLABs with ICT (online assignment, computer simulations) were represented the least. The strongest demographic characteristic affecting the teachers' use of PLABs in chemistry lessons was their gender, followed by age and teaching subjects. The teachers' education, teaching experience and school types were nonsignificant characteristics.

Although these influences were small, a trend regarding more frequent use of PLABs can be noticed in male chemistry/physics teachers under 36 years of age, which could lead to further research to establish the equivalence of samples. To get more detailed demographic profiles, future studies can include a questionnaire with open-ended questions in items regarding age and teaching experience.

\section{Acknowledgements}

The authors would like to thank the chemistry teachers throughout Croatia who participated in this research for being willing to share their experience. The authors would also like to thank the colleagues who contributed to the development of the questionnaire.

\section{References}

1. A. Hofstein, V. N. Lunetta, Sci. Educ. 2004, 88, 28-54. DOI:10.1002/sce.10106

2. G. Tsaparlis, in: J. K. Gilbert, D. Treagust (Eds.): Multiple representations in chemical education, Springer, Dordrecht, The Netherlands, 2009, pp. 109-136.

3. A. H. Johnstone, J. Chem. Educ. 1993, 70, 701-705. DOI:10.1021/ed070p701

4. A. H. Johnstone, A. Watt, T. U. Zaman, Phys. Educ. 1998, 33, 22-29. DOI:10.1088/0031-9120/33/1/016

5. D. P. Ausubel, Educational psychology: A cognitive view. Holt, Rinehart and Winston, New York, NY, 1968.

6. J. Sweller, J. J. G. Van Merrienboer, F. G. W. C. Paas, Educ. Psychol. Rev. 1998, 10, 251-296. DOI:10.1023/A:1022193728205

7. A. H. Johnstone, H. El-Banna, Stud. High. Educ. 1989, 14, 159-168. DOI:10.1080/03075078912331377486

8. A. H. Johnstone, R. J. Sleet, J. F. Vianna, Stud. High. Educ. 1994, 19, 77-87. DOI:10.1080/03075079412331382163

9. D. Lair, Center for Research on Teaching Excellence. 2011, 1-12. Advance online publication, https://cloudfront.escholarship.org/dist/prd/content/qt8623f3zs/qt8623f3zs .pdf, (accessed: April 20, 2018)

10. A. Logar, C. Peklaj, V. F. Savec, Acta Chim. Slov. 2017, 64, 661-671. DOI:10.17344/acsi.2017.3544
11. T. M. Winberg, C. A. R. Berg, J. Res. Sci. Teach. 2007, 44, 1108-1133. DOI:10.1002/tea.20217

12. H. Y. Agustian, M. K. Seery, Chem. Educ. Res. Pract. 2017, 18, 518-532. DOI:10.1039/C7RP00140A

13. G. D. Chittleborough, M. Mocerino, D. F. Treagust, J. Chem. Educ. 2007, 84, 884-888. DOI:10.1021/ed084p884

14. J. Schmidt-McCormack, M. Muniz, E. Keuter, S. K. Shaw, R. Cole, Chem. Educ. Res. Pract. 2017, 18, 749-762. DOI:10.1039/C7RP00078B

15. J. L. Chaytor, M. Al Mughalaq, H. Butler, J. Chem. Educ. 2017, 94, 859-866. DOI:10.1021/acs.jchemed.6b00850

16. D. Spagnoli, L. Wong, S. Maisey, T. D. Clemons, Chem. Educ. Res. Pract. 2017, 18, 26-44. DOI:10.1039/C6RP00157B

17. M. Rollnick, S. Zwane, M. Staskun, S. Lotz, G. Green, Int. J. Sci. Educ. 2001, 23, 1053-1071. DOI:10.1080/09500690110038576

18. S. K. E. O’Sullivan, T. G. Harrison, Acta Didact. Napocensia. 2016, 9, 51-64, https://files.eric.ed.gov/fulltext/EJ11034 33.pdf, (accessed: April 20, 2018)

19. N. Reid, I. Shah, Chem. Educ. Res. Pract. 2007, 8, 172-185. DOI:10.1039/B5RP90026C

20. S. E. Kulevich, R. S. Herrick, K. V. Mills, J. Chem. Educ. 2014, 91, 1207-1211. DOI:10.1021/ed400377a

21. M. D. Carter, S. S. Pierce, A. D. Dukes III, R. H. Brown, B. S. Crow, R. L. Shaner, et al., J. Chem. Educ. 2017, 94, 1094-1097. DOI:10.1021/acs.jchemed.6b00964

22. M. C. Roslaniec, E. M. Sanford, J. Chem. Educ. 2010, 88, 229231. DOI:10.1021/ed100487a

23. E. Yildirim, Procedia Soc. Behav. Sci. 2012, 46, 2352-2355. DOI:10.1016/j.sbspro.2012.05.483

24. Y. Hao, K. S. Lee, Comput. Hum. Behav. 2016, 57, 250-260. DOI:10.1016/j.chb.2015.12.022

25. D. Reilly, D. L. Neumann, G. Andrews, Res. Sci. Educ. 2019 49, 25-50. DOI:10.1007/s11165-017-9630-6

26. A. O. Alazzam, A. R. Bakar, R. Hamzah, S. Asimiran, IES. 2012, 5, 229-243. DOI:10.5539/ies.v5n6p229

27. A. Aslan, C. Zhu, Br. J. Educ. Technol. 2017, 48, 552-570. DOI:10.1111/bjet.12437

28. J. Gil-Flores, J. Rodríguez-Santero, J. J. Torres-Gordillo, Comput. Hum. Behav. 2017, 68, 441-449. DOI:10.1016/j.chb.2016.11.057

29. T. Teo, M. Zhou, Interact. Learn. Environ. 2017, 25, 513-527. DOI:10.1080/10494820.2016.1143844

30. R. Scherer, F. Siddiq, T. Teo, Comput. Educ. 2015, 88, 202214. DOI:10.1016/j.compedu.2015.05.005

31. J. H. L. Koh, C. S. Chai, C. C. Tsai, Educ. Technol. Soc. 2014, 17, 185-196, https://media.proquest.com/media/ hms/PFT/1/7Aml7?_s=WWZgKh5cL48aPy8nXz 8nMQdzUu0\%3D, (accessed: November 15, 2019)

32. M. K. Seery, J. Chem. Pharm. Sci. 2010, 3, 1-3, http://www. dit.ie/media/ditlttc/documents/lttcresources/Using\%20 Pre-Lecture\%20 Resources \%20in\%20your\%20teaching.pdf, (accessed: January 24, 2017)

33. S. Smerdel, M. Zejnilagić Hajrić, Nat. Sci. Educ. 2017, 14, 90 96, https://journals.indexcopernicus.com/search/article?articleId $=1883115$, (accessed: November 16, 2019) 
34. K. S. Taber, Res. Sci. Educ. 2018, 48, 1273-1296.

DOI:10.1007/s11165-016-9602-2

35. H. W. Lilliefors, J. Am. Stat. Assoc. 1967, 62, 399-402.

DOI:10.1080/01621459.1967.10482916

36. J. Cohen, Statistical power analysis for the behavioral sciences. Lawrence Erlbaum Associates, Hillsdale, New York, 1988.
37. T. N. Hrin, D. D. Milenković, M. D. Segedinac, S. Horvat, J. Serb. Chem. Soc. 2016, 81, 1455-1471, https://shd-pub.org. rs/index.php/JSCS/article/view/3593/352, (accessed: April 24, 2018)

38. W. L. Neuman, Social research methods: Qualitative and quantitative approaches (7th ed.). Pearson Education Limited, Harlow, UK, 2013.

\section{Povzetek}

Predlaboratorijske aktivnosti so načrtovane $\mathrm{z}$ namenom pritegnitve zanimanja s strani učencev do nekaterih aspektov eksperimenta, ki ga nameravajo izvesti. Predhodne raziskave so pokazale, da tovrstne aktivnosti zmanjšajo kognitivno breme $\mathrm{v}$ laboratoriju in izboljšujejo učinkovitost laboratorijskega dela učencev. Ta raziskava temelji na primerjavi pomembnosti demografskih karakteristik, ki vplivajo na učiteljevo uporabo predlaboratorijskih aktivnosti pri kemijskih predmetih. V okviru kvantitativne raziskovalne ankete je sodelovalo 166 učiteljev kemije iz vseh regij Hrvaške. V predlaboratorijskem pouku so se učitelji najpogosteje poslužili diskusije in uporabe predlog medtem ko so najmanj uporabljali računalniške simulacije. Tri karakteristike, ki vplivajo na učiteljevo uporabo predlaboratorijskih aktivnosti pri kemiji, so spol, starost in področje poučevanja. Izobrazba učiteljev, učne izkušnje in vrsta šole predstavljajo nepomembne karakteristike. 